\title{
Rethinking on China's Higher Legal Education Reform
}

\author{
Li Ruohan
}

\begin{abstract}
In the past 70 years since the founding of New China, its legal education has developed from restoration at the beginning to continuous prosperity right now, a modern legal education system with relatively large-scale, reasonable structure and high quality characteristics has been preliminarily improved. Due to historical and institutional reasons, there are also many practical problems on China's higher legal education mode, such as the lack of humanistic spirit, the disconnection between theoretical education and legal profession, and the anomie of university management. Its current educational concept, curriculum and teaching content of legal education can not meet requirements of social politics and economic development. Therefore, it is necessary to further adjust and improve the education mode, education level and education idea of our higher legal education to constantly improve its education quality.
\end{abstract}

Index Terms-Higher legal education, vocational education, law talents training, education reform.

\section{INTRODUCTION}

Looking back on the 70 years history of China's higher legal education, two different periods of its development can be divided by reform and opening up in 1978. Look back on 30 years from then, China's higher legal education was known as "political command" mode by learning from the experience of former Soviet Union, which was suffered setbacks or even basically paralyzed in 1970s. Since 1980s, China's higher legal education has begun to reconstruct and has initially formed a socialist legal education model with Chinese characteristics. China's legal education has recorded and reflected about 70 years of tortuous development of China's economic, political, cultural and social progress, and also has made remarkable achievements. Today China's higher legal education is at a new crossroads. On the one hand, its size and quantity has shown an unprecedented prosperity; on the other hand, its structure and quality also has many deep-seated contradictions. Its not just today, the problem of China's higher legal education has been deep-rooted for several decades, now it is time to make a choice. All administrators, educators, educatees and researchers of legal education, are obliged to search for a bright and solemn road for the reform of higher legal education in light of China's reality.

\section{DifFiculty FACED By ChinA's Higher Legal EDUCATION}

Manuscript received August 25, 2018; revised June 3, 2019. This work was supported in part by the China National Social Science Foundation 17CFX046.

Li Ruohan is with the National University of Defense Technology, Changsha, China (e-mail: j.liruohan@ @otmail.com).

\section{A. Lagging Behind Higher Legal Education Management Mode}

Since Qing Dynasty, China's modern higher legal education has been centralized controlled and arbitrary interfered by the government [1]. Since reform and opening up, with the development of our education system reform, the functions of the government's educational administration have changed greatly, and the autonomy of universities has expanded continuously. But our education system has not completely shaken off the higher centralized management mode by now. There are also many anomie, disorder and confusion problems in our higher legal education. First of all, the administrative control mode still exists. State and provincial education authorities directly control over universities' education mechanism, by controlling the appointment of universities' officials, staffs, education funds and enrollment limitation. Universities in this instance are only a tool for competent departments to perform their administrative functions, and are so difficult to develop independently. Private colleges are relatively free, but due to the lack of government's support and social identity, their education scale and social influence is small and weak. Secondly, although the Law Teaching Steering Committee was set up in 1997 by the Education Ministry, which is composed of the administrators of the Education Ministry and scholars from some colleges, universities and scientific research institutions, there is neither a long-term mechanism nor a rigid authority for the committee. Members of the committee are busy with their own stuffs, and they can only attend annual meeting in one or two days [2]. So it is difficult to give systematic, long-term and targeted planning on various issues of legal education.

For our higher legal education, our competent educational authority does not set up a unified access for higher legal education, or a standardized access for universities to open up law majors, or a rigid supervision mechanism for sifting out poor quality institutions. For this reason, any university that meets the basic requirements of its establishment can decide to set up a law school or law profession on its own, resulting in legal education run out of control, and the quality of education is uneven.

\section{B. Short-Term Interest Driven Higher Legal Education Market}

In the years before reform and opening up, as everyone knows, China's higher legal education was obviously oriented by political needs. Since 1978, it came to a new time of more free and favourable circumstances. The country of new time needs a large number of legal personnel to enrich the ranks of judges, prosecutors, lawyers and judicial administration in a relatively short period of time. The government also needs a large number of officers with legal knowledge to engage in 
legislation, administration and law enforcement affairs. Market economy also requires companies and enterprises to attach more importance to legal talents. Legal education is more and more popular in society and people's life. Law major has become the hottest majors in universities. This situation is really great for our higher legal education institutions, and made it flourish. As a result, law colleges and departments have been set up in various universities, not only in comprehensive universities but also in science and engineering universities. In addition to undergraduate colleges and universities, many junior colleges, higher vocational colleges and adult education colleges, have also set up law specialties and opened up legal courses. By 1990s, after a trend of large-scale development, China's higher legal education institutions have grown more than 100 -fold in past 30 years, from the first five law colleges to more than 600 law schools or colleges all over the country (now the amount is over 650) [3]. But to a considerable extent, the motivation for education institutions to run up a law school is driven by short-term personal interests. Because at that time running a law school means getting more government financial support, enterprise donation, and social reputation. By adding law specialties and expanding their enrollment, an education institution can get huge economic benefits and other potential benefits. But blindly following the trend brings problems. Some colleges and universities without a long history of running law schools also join this trend, although they do not have corresponding teaching conditions (perfect teaching equipment, advanced teaching ideas, rich teaching experience, complete teaching system and experienced law teachers) for running a law school. In some law schools, the proportion of teachers and students is seriously unbalanced; its teaching sources and materials are seriously inadequate; students' learning and living conditions are harsh, the running quality of law school is obviously poor. But in the Sellers' market, weaker teaching resources, poorer education quality, unskilled law graduates, and all the negative consequences can not stop legal education institutions gain huge profits and produce low quality "products". This phenomenon is also called "adverse selection" by economics which means consumers would pay a higher price for a lower product.

\section{Complex Level of Higher Legal Education}

Before 1980s, China's higher legal education was concentrated in law schools and colleges. Its education form is mainly undergraduate education. Since 1980s, various forms of legal education have emerged, such as: secondary vocational education, post-secondary education, undergraduate education, and postgraduate education (contains master education and doctoral education).

Among them, secondary vocational legal education the lowest level of legal education which is mainly run by judicial schools of different provinces; secondary school graduate can participate in national judicial examination after obtaining a post-secondary degree or undergraduate degree through continuing education.

Post-secondary education has there forms, including full-time vocational education, short-term vocational education, and self-taught higher education which can be held by evening universities, correspondence colleges, radio and television universities, amateur workers' universities, or management cadres colleges, those institutions could be Independent or affiliated to ordinary universities. Students can participate in national judicial examination after graduation; they can get bachelor's degree through national upgraded examination or directly apply for master's degree by participating postgraduate examination of ordinary universities.

Undergraduate legal education is mainly undertaken by full-time colleges and universities, which is also the most perfect and mature stage of legal education in China. In law school, students will receive a four-year legal professional education, including legal theory and legal vocational training. After graduation, students can engage in legal profession or continue their graduate education.

Graduate legal education has two levels: postgraduate education and doctoral education. In the first level, there are legum magister and juris master, which both have solo-certificate (only with diploma) and double certificate (with diploma and degree). Legum magister was first designed for postgraduate students with law degree, just like juris master designed for those with no-legal background. But their borders are increasingly blurred now, the enrollment scale of Legum magister is shrinking, and juris master's enrollment is expanding year by year, because the former are usually state-funded students, while the latter can generate a huge income for law schools. There is no difference of the two types of students in taking part in national judicial examination, applying for doctoral education, or looking for a job.

There are so many levels, forms and institutions of legal education in China, which always make foreign counterparts feel complicated. Its negative impact has become a deep pain for legal professionals and those who aspire to engage in legal profession. Such as, the ultra low employment rate in junior colleges (including secondary and post-secondary institutions); the poor quality of law graduates; the blurred boundary between professional masters (legum magister and juris master), and so on.

\section{Uneven Quality of Teaching Staffs}

It is interesting to note that there is a rather fine division of disciplines within the field of law, in contrast to the lack of enough knowledge accumulation of the divided fields. At the early stage of the restoration of our legal education, it is helpful to build up a legal discipline system as soon as possible, so teachers engaged in legal education with general knowledge of law is very popular. But today, the fine discipline division of law has created much obstacle for a legal scholar with no specialty to improve his teaching and researching abilities. Many teachers entered the legal education field from 1970s are still working, and occupy important positions in colleges and universities. There is a great deal of controversy and disagreement between the two generations on educational ideas, ways and methods. As a whole, the outmoded knowledge and single knowledge structure are defective products of the times.

At the same time, under the background of marketization, the flow of law teachers is also a weak point of China's higher legal education. For universities and colleges, the motive of 
introduction of talents is to improve their strength of teaching and research which could be reflected in records of their undergraduate or postgraduate degree discipline evaluation. For law talents, the motivation attracting them to change jobs is to get better treatment, economic and welfare benefits. Excellent law staffs are flowing from junior colleges to undergraduate universities, from ordinary universities to top universities, but strange thing is the more popular the university is, the worse the economic treatment be provided. At the moment, the anomaly is that the lowest bidder always gets best goods, which makes "the rich ever richer" [4]. In another hand, in order to meet the needs of increasing enrollment scale, colleges and universities those who are disadvantaged in talent competition have to hire law staffs who are lack teaching experience or with poor research ability This creates more "bubbles" of education than promoting their quality of running a law school. Even in top law schools, unreasonable structure of teachers still exist. Young teachers, after entering teaching posts, have to take on heavy teaching works in the first few years, which makes it difficult for them to achieve real substantive improvement in teaching and scientific research ability. Under current educational management and evaluation mechanism, it is difficult for young teachers to get real reward for their heavy work, their efforts and gains are seriously disproportionate. Those young teachers who have lost faith in legal education have turned to other high-paying professions. Especially in recent years, the absolute loss of talents in legal education is serious.

\section{E. Uncompetitive Graduates Majoring in Law}

Since 1978, with the establishment of law specialties in almost all colleges and universities, the number of law graduates is increasing rapidly. The excessive expansion of the scale of legal education has caused the shortage of teaching resources, and the quality of legal education has caused widespread concern.

According to a statistic by MyCOS Research Institute, from 2012 to 2017 , the employment rate of law graduates is less than $85 \%$, ranked at the end of liberal arts graduates 5 consecutive years. The graduate employment difficulty index (graduate sample size/recruitment demand sample size) of campus recruitment shows law has surpassed economics and philosophy to become the most difficult major in employment in 2017. To find a suitable job is becoming more and more difficult for many law graduates. It is not uncommon that law graduates in famous universities (such as Peking University and Tsinghua University) can not able to find jobs immediately after their graduation. On the one hand, the relationship between supply and demand of law graduates is seriously imbalanced, the law-related positions offered by the society for law graduates are becoming less and less, and the standard of employment is getting increasingly grim; on the other hand, the quality and ability of law graduates are uneven, and the overall level of education quality is worrying.

At present, it has become an undoubted fact that the cost performance ratio of law graduates has dropped and the employment rate is such low. A related problem is that the government's monitoring mechanism of higher education teaching quality is inefficient. The teaching quality monitoring of higher education is mainly carried out by the random teaching inspection organized by the government education department. It is not mature now, and it is powerless [5]. And there are also lack of self-restraint mechanism and a complete, institutionalized and standardized internal guarantee system for teaching quality in colleges and universities themselves.

\section{FutURE PROSPECTS OF HighER LEGAL EDUCATION IN CHINA}

\section{A. Readjusting the Function and Orient of Higher Legal Education}

When the relationship between legal education and legal profession is criticized, legal professional ethics and skill education are widely called for, and the relationship between law and justice is overall questioned, it means that our current legal education needs to be repositioned. Legal education, as an important part of national legal practice, should play a leading role in the trend of legal thought of the times and enhance the legal literacy of the whole society. It should also assume the responsibility of building a social ethic system and maintaining the mainstream values of the society. The mission of legal education is to enhance people's awareness of justice, broaden the road, train the guardians and build the ladder of social justice. This goal should be the benchmark for future legal education of China. Legal education shoulders the historical mission of training high-quality law talents for the whole society [6].

At present and in the future, the overall function of China's legal education is to cultivate juridical personality who believe in the rule of law and are loyal to justice. They should guard and build up the ladder of social justice by virtue of their wisdom, conscience and courage, so that everyone in society can reach the highland of justice. In our construction of a country under the rule of law, legal education must be professionalized and professionalized. It is necessary to readjust China's higher legal education mode from general education to the combination of general education, professional education and elite education. Its training goal should be changed from the knowledge-based talents to the joint training of law application talents, law research talents and social management talents. We should change the traditional concept of equating legal education with one-off academic education in law schools. Legal education includes not only academic and degree education, but also non-degree education; not only legal knowledge education, but also legal belief, legal ethics and legal vocational education.

\section{B. Establishing a Comprehensive Evaluation System for Educational Quality}

Over the past 40 years, we have basically completed the historical task of scale construction and quantity accumulation of legal education. Now and in the future we should transfer the theme of higher legal education to its quality in an all-round way. The training of legal talents needs quality-oriented education mode which should attach importance to cultivate student's innovative spirit and practical ability. To improve the quality of higher legal education cannot rely solely on education institutions. We 
should establish a trinity system of government's macro-control, educational institutions' self-management and social's market-demand regulation.

First of all, the government should focus on legal norms, policy guidance and investment restrictions on legal education from a macro perspective. It should construct the admission system of legal education which is in line with China's reality by properly raising the threshold of legal education. A competition elimination mechanism should be set up to promote the survival of the fittest in legal education institutions to improve our higher legal education.

Secondly, institutions of higher learning are the main bodies of legal education who should establish scientific and standardized legal education management system, teaching supervision system, teaching consultation and evaluation system, education quality evaluation system and education quality reward and punishment system to improve the quality of legal education.

Again, Public, community and students' cognition of legal education is an important index to evaluate the quality of legal education. By connecting the export of legal talents in education institutions with the demand of social professional posts, the economic market can play a regulatory role in the supply and demand, that could do help to improve the quality of legal education. We can evaluate the quality of legal education through the relationship between the input and output of legal products and the supply and demand of talent market. Educational quality assessment institutions can help to do this evaluation, but payments required.

\section{Setting up Law School Evaluation and Assessment Mechanism}

At present, China's higher legal education institutions are set up in a large scale, but somewhat disorienting. Looking for the future, education institutions should take the road of differentiation in training law talents. The education of law schools should be divided into three categories: academic type, practical type and characteristic type. Academic law schools mainly train theoretical legal talents engaged in law research and legal education. Practical law schools mainly train practical legal talents engaged in legal profession. Characteristic law schools mainly focus on the training of law professionals with professional characteristics, such as finance and economics, agriculture and forestry, and so on. Whether academic law schools, practical law schools, or characteristic law schools, their higher legal education can be subdivided into elite education and general education. Elite education can cultivate academic, practical and characteristic multi-level legal talents. Ordinary legal education only provides basic legal knowledge and legal methods which can do help to students' future work and life.

Based on the above classification, we can establish the admission criteria for different types of higher legal education to classify existing legal education institutions, and carry out regular assessment within a certain period of time according to the mechanism. Law schools that fail to meet the elite standards should be relegated to ordinary law schools; ordinary law schools that meet the higher standards should be upgraded to elite law schools; law schools that fail to meet the general standards, whether academic, practical or characteristic type, the competent education authorities could revoke their law majors or stop their enrollment as a punishment.

\section{Adjusting Administrative Level of Higher Legal Education with Diploma}

At present, there are some problems in all levels of higher legal education with diploma. Such as the poor quality of secondary legal education, the low employment rate of law school graduates, and confusing definition of legum magister and juris master [7]. Optimizing and adjusting traditional structure of our higher legal education system is an inevitable choice in the future.

Nowadays, the goal of China's higher legal education is to train law application talents, legal research talents and social management talents. Among them, the first type personnel have relatively low requirements for their legal education. Even though, their profession also requires practitioners to have a high degree of professional knowledge and skills. So secondary vocational legal education has fulfilled its mission entrusted by the times. It can no longer meet the needs of economic, political and cultural development in modern society, which can only cause waste of educational resources such as infrastructure, time, funds and teachers. Therefore, it should be replaced by other vocational education types.

The main problem of china's post-secondary vocational education lies in the chaotic diplomas of different educational institutions. Few people can distinguish the difference of post-secondary diplomas among adult education, distance learning and self-taught. But the time, money and energy required to get those diplomas are entirely and totally different. Therefore, it is necessary to standardize post-secondary vocational education by establishing basic standards of entrance examination, credits and graduation requirements, standardizing the course structure and the curriculum arrangement.

At present, the legal education of at the tertiary level is relatively mature, and its educational content should be inclined to vocational skills and professional spirit in the future.

For the professional legeal education of graduate students, we should distinguish the boundaries of legum magister and juris master according to their training objectives rather than confusing them. The education of legum magister is aiming at training academic and professional law talents, who will be employed mainly by legal education and research institutions after graduation. The legeal education of juris master is aiming at the cultivation of compound and applied law talents, who could be absorbed into legal related professions as legal department of enterprise after graduation. Of course, if they want to work as judges, prosecutors, and lawyers, both of the two types of postgraduates can get their professional qualification by taking the National Judicial Examination; if they want to further their studies, they can also apply for a doctorate.

\section{E. Reorganizing Law Faculty Structure and Improving Higher Legal Education Methods}

Faced with the current situation of brain drain, irrational structure and uneven quality of our law faculty structure, our 
higher legal education reform should focus on following aspects in the future. Firstly, we should reform the management and evaluation mechanism of law faculties to avoid managing and evaluating law faculties by "administrative achievements" or by some single standard such as class hours, research achievements, or enrollment quantity. Abolish different standards for different law subjects in teaching and scientific research in same educational level and same institution, instead of our "unequal treatment" mode. Secondly, we should change the internal structure of law faculties by following the talent market flowing mechanism. It is necessary to balance the teaching echelon of old and new teachers, and to give young teachers the environment for their growth and necessary guidance [8]. Above all, there is a need to improve the economic and living treatment of young teachers by providing them with more favourable scientific research and teaching conditions, other than providing them with lower treatment in order to take care of the vested interests as before.

And we should change our status quo of theoretical teaching mode into a practical teaching mode. The reform could be carried out in three aspects. Firstly, enhance teaching interaction by widely adopting discussion and argumentative teaching method instead of traditional lecture-teaching method to put students in the main position of teaching, and change their concerns from books to practice, from rigid memory to learning to think, from passive acceptance to active participation. Secondly, it is important to adopt case teaching method, which can help to improve students' deep understanding of legal interpretation and application, and to train their legal thinking following inherent logic of law. Thirdly, clinical law courses can be offered to enable students to acquire a preliminary understanding of the actual situation of the legal profession, and to cultivate their awareness and cognition of legal profession. Of course, there is no need to provide such courses for legal professionals receiving continuing education.

\section{F. Positive Interaction among Legal Education, Judicial Examination and Legal Profession}

Facing the disconnection between legal education and legal profession in China, we mush promote the positive interaction among legal education and legal profession.

Firstly, the resources of legal education and legal profession will be integrated, and law schools and professional institutions should share teachers and information. This goal will be achieved through the establishment of legal profession and student exchange system [9]. In this system, Courts, procuratorates and law firms would provide practical opportunities for college students, while colleges and universities should provide opportunities for those legal professions to pursue further studies in return.

Secondly, in the process of rule of law, the professionalization of judicature is a general trend. Therefore, the content and training objectives of legal education should adapt to the direction and trend of judicial professionalization. The reform of national judicial examination should guide the reform of higher legal education to achieve this positive interaction. The national judicial examination should be strictly regulated. Only those graduates who have received professional legal education and obtained a degree in law can take the judicial examination. Graduates with no-legal undergraduate degree must be trained in law schools designated by the state and get their certification before they can take the examination. The traditional contents of judicial examination should also be reformed. The examination contents should be shifted from examining students' legal professional knowledge to examining their ability to think and solve practical problems with legal knowledge. For graduates who want to engage in specialized legal professions, passing national judicial examination does not mean getting a job. They also need to take part in legal vocational training in law firms or pass the civil service examination organized by government. This will avoid the drawbacks of "one examination determines a whole life".

\section{CONCLUSION}

Looking back on the development of legal education of China over the past 70 years, from the early days of the founding of the People's Republic of China to the reform and opening up, China's legal education has experienced three stages: the initial stage (1949-1956), the setback stage (1957-1965) and the stagnation stage (1966-1976). Since 1978, China's legal education has entered a new period, which mainly experienced four stages of development: rapid recovery and development period (1978-1987); standardization construction period (1988-1997); large-scale development period (1998-2007); adjustment development period (2007-present). Our legal vocational education has accomplished three transformations, namely the transformation from makeup training, temporary training to systematic and standardized training; the transformation from popularization and knowledge training to professional and elite training; and the transformation from academic education to vocational continuing education. Our legal education model has taken shape initially transformations: the first is legal education has transformed from a single popularization of legal provisions to an all-round promotion of legal governance; the second is legal education has transformed from political leadership to a institutionalization, standardization and legalization mode; the third is legal education has transformed from a tool of governance to a method raising the awareness of the whole people.

While fully affirming the achievements over the past 70 years, we should also be aware of the challenges facing China's legal education. The next 30 years in China will be a crucial period for the sound and rapid development of the socialist market economy, for the establishment of a harmonious socialist society and for the construction of socialist democracy. Socialist harmonious society is a society governed by democracy and the rule of law. Socialist market economy is an economy governed by law. Socialist democratic politics is a politics governed by law. Only by fully implementing the basic strategy of governing the country by law, speeding up the construction of a socialist country ruled by law, and applying the rule of law and other institutional norms to implement the scientific outlook on 
development, can China's rule of law be guaranteed. The rule of law era is an era of reform, innovation and development. It is an era full of competition. It calls for the prosperity and development of China's jurisprudence, which requires the deepening reform and innovation of legal education. China's legal education in the future should be guided by the theory of scientific development and harmonious construction. Integrating legal education into the general strategy of implementing the basic strategy of ruling the country according to law can protect our legislation, judicature, administration and law-abiding. Therefore, we need to scientifically adjust and perfect our higher legal education in aspects of function orientation, education mode, education institution, education level, and education idea in the future.

\section{CONFLICT OF INTEREST}

The author declares no conflict of interest.

\section{AUTHOR CONTRIBUTIONS}

The paper is written by the author independently.

\section{REFERENCES}

[1] D. X. Guo, "On the reference of international advanced legal education mode to China's reform," Journal of Henan University of Economics and Law, vol. 2, p. 166, April 2013.

[2] X. Y. Zhao, "A comparative study of the mode of legal education Also on the choice of legal education mode in China," Journal of Liaoning Administration College, vol. 7, p. 94, July 2011.

[3] D. X. Ji. "A comprehensive reflection and prospect of China's legal education," Journal of China University of Political Science and Law, vol. 4, p. 51, August 2010.
[4] J. X. Zhu, "Comparison and innovation of higher legal education mode," Journal of Higher education in Heilongjiang, vol. 7, pp. 135-136, July 2005.

[5] M. Y. Zhu, "The enlightenment of American and French legal education models to China's higher law education," University Education in China, vol. 12, p. 80, December 2015.

[6] Y. Q. Hu, "Reflection and reconstruction of the training mode of applied law talents in China," Law Review, vol. 1, p. 131, February 1999.

[7] Y. Han, "The difficult position of Chinese legal education and the replacement of educational mode," Learning and Practice, vol. 4, p. 110, August 2012.

[8] Z. Jiao and P. P. Ling, "Confusion and disabuse in the mode of legal education," Qinghai Social Sciences, vol. 5, p. 180, October 2008.

[9] J. M. Fan, "Analysis of the reform of law education mode," Henan Social Sciences, vol. 21, no. 8, p. 77, August 2013.

Copyright (C) 2019 by the authors. This is an open access article distributed under the Creative Commons Attribution License which permits unrestricted use, distribution, and reproduction in any medium, provided the original work is properly cited (CC BY 4.0).

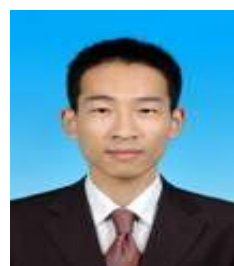

Li Ruohan was born in Yuzhou city, China on October $9^{\text {th }} 1984$. He was graduated in the Law School of Wuhan University (Wuhan city, China) and got his doctoral degrees in 2015, majoring in international law. He also has been a visiting scholar of University of Washington (Seattle, U.S.A.) in 2014.

$\mathrm{He}$ is the associate professor of National University of Defense Technology (Changsha, China), the member of Chinese Legal Orgnization and the member of Chinese Society of International Law. Li Ruohan. Basic Principles of Jus Post Bellum, Peking: Law Press, 2017. His research interests are legal education and international law. 